\title{
Root system distribution and yield of 'Conilon' coffee propagated by seeds or cuttings
}

\author{
Fábio Luiz Partelli(1), André Monzoli Covre(1), Marcos Goes Oliveira(1), Rodrigo Sobreira Alexandre(1), \\ Edney Leandro da Vitória(1) and Marcelo Barreto da Silva ${ }^{(1)}$
}

\begin{abstract}
(1)Universidade Federal do Espírito Santo, Rodovia BR-101 Norte, Km 60, Bairro Litorâneo, CEP 29932-540 São Mateus, ES, Brazil. E-mail: partelli@yahoo.com.br, andrecovre@hotmail.com, mgoesoliveira@hotmail.com, rodrigosobreiraalexandre@gmail.com, vitoria.edney@gmail.com, marcelobarretodasilva@gmail.com
\end{abstract}

\begin{abstract}
The objective of this work was to evaluate the root system distribution and the yield of 'Conilon' coffee (Coffea canephora) propagated by seeds or cuttings. The experiment was carried out with $2 \times 1 \mathrm{~m}$ spacing, in an Oxisol with sandy clay loam texture. A randomized complete block design was used, following a 2x9x6 factorial arrangement, with two propagation methods (seeds and cuttings), nine sampling spacings $(0.15,0.30$, $0.45,0.60,0.75$, and $0.90 \mathrm{~m}$ between rows, and $0.15,0.30$, and 0.45 between plants within rows), six soil depths $(0.10-0.20,0.20-0.30,0.30-0.40,0.40-0.50$, and $0.50-0.60 \mathrm{~m})$, and six replicates. Soil cores $\left(27 \mathrm{~cm}^{3}\right)$ with roots were taken from 12 experimental units, 146 months after planting. The surface area of the root system and root diameter, length, and volume were assessed for 13 years and, then, correlated with grain yield. The highest fine root concentration occurred at the superficial soil layers. The variables used to characterize the root system did not differ between propagation methods. Moreover, no differences were observed for net photosynthetic $\mathrm{CO}_{2}$ assimilation rate, stomatal conductance, internal $\mathrm{CO}_{2}$ concentrations, and instantaneous water-use efficiency in the leaves. Cutting-propagated plants were more productive than seed-propagated ones.

Index terms: Coffea canephora, root diameter, root length, root volume, vegetative propagation.

\section{Distribuição do sistema radicular e produtividade do café 'Conilon' propagado por sementes ou estaquia}

Resumo - O objetivo deste trabalho foi avaliar a produtividade e a distribuição do sistema radicular do café 'Conilon' (Coffea canephora) propagado por sementes ou estaquia. O experimento foi realizado no espaçamento $2 \times 1 \mathrm{~m}$, em Latossolo com textura franco-argilo-arenosa. Utilizou-se o delineamento experimental de blocos ao acaso, em arranjo fatorial $2 \times 9 \times 6$, com dois métodos de propagação (semente e estaca), nove espaçamentos $(0,15,0,30,0,45,0,60,0,75$ e $0,90 \mathrm{~m}$, nas entrelinhas, e $0,15,0,30$ e 0,45 entre plantas), seis profundidades $(0,10-0,20,0,20-0,30,0,30-0,40,0,40-0,50$ e $0,50-0,60 \mathrm{~m})$ e seis repetições. Foram retirados monólitos $\left(27 \mathrm{~cm}^{3}\right)$ de solo com raízes de 12 unidades experimentais, 146 meses após o plantio. A área superficial do sistema radicular bem como o diâmetro, o comprimento e o volume das raízes foram avaliados por 13 anos e correlacionados à produtividade de grãos. A maior concentração de raízes mais finas ocorreu nas camadas superficiais do solo. As variáveis utilizadas para caracterizar o sistema radicular não diferiram entre os métodos de propagação. Além disso, não se observaram diferenças quanto à taxa de assimilação fotossintética líquida de $\mathrm{CO}_{2}$, nem quanto à condutância estomática, às concentrações internas de $\mathrm{CO}_{2}$ e à eficiência do uso da água nas folhas. Plantas propagadas por estaquia foram mais produtivas do que as propagadas por sementes.

Termos para indexação: Coffea canephora, diâmetro de raízes, comprimento de raízes, volume de raízes, propagação vegetativa.

\section{Introduction}

Seed-derived plants from Coffea canephora Pierre ex A. Froehner are both genetically and morphologically heterogeneous, which results in substantial variations in plant architecture, disease resistance, maturation time, seed size and shape, and yield (Conagin \&
Mendes, 1961; Bragança et al., 2001). Therefore, commercial propagation of the species has been done by cuttings, which overcomes the variability caused by seed propagation. Cutting-propagation is physiologically viable and ensures maximum crop homogeneity, besides other desirable traits, especially grain maturation, fruit yield and size, and plant vigor 
(Weigel \& Jurgens, 2002; Paiva et al., 2012). Moreover, this technique has allowed the establishment of coffee crops in areas with biotic or abiotic limitations (Miranda et al., 2011; Paiva et al., 2012).

Commercial 'Conilon' coffee fields use seedlings from cuttings. However, there are important questions related to the development of plants derived from cuttings, as for their ability to grow in depth and to anchor and support adult plants.

Root system characteristics are known to differ according to species, genotype, plant age, season, climate, plant density, root diameter, biotic stresses, and soil texture and structure (Lynch, 1995). Current studies addressing the characteristics of root system of coffee plants are still inconclusive as to its distribution in the soil profile, as well as to root physiology, size, and volume (Rena \& Guimarães, 2000; Carvalho et al., 2008; Andrade Júnior, 2013). Therefore, additional knowledge on coffee root system can improve crop management, since a well-developed root system can enhance water and nutrient uptake and, also, increase the efficiency of soil-applied fungicides and insecticides, which can directly affect plant yield and tolerance to drought and other stresses (Franco \& Inforzato, 1946; Rena \& Guimarães, 2000; Carvalho et al., 2008).

The objective of this work was to evaluate the root system distribution and the yield of 'Conilon' coffee (Coffea canephora) propagated by seeds or cuttings.

\section{Materials and Methods}

This experiment was carried out in Vila Valério (18 $57^{\circ} \mathrm{S} ; 40^{\circ} 18^{\prime \prime} \mathrm{W}$, at approximately $150 \mathrm{~m}$ altitude), in the north-western portion of the state of Espírito Santo, Brazil. The climate type in the region is tropical, with hot and humid summers and dry winters. The annual rainfall is $1,200 \mathrm{~mm}$, and precipitation volume concentrates between November and January. Annual average temperature is $23^{\circ} \mathrm{C}$, with $29^{\circ} \mathrm{C}$ maximum mean and $18^{\circ} \mathrm{C}$ minimum mean (Comitê de Bacia Hidrográfica do Rio Doce, 2013). The soil in the area was classified as Typic Hapludox (Latossolo Vermelho Amarelo, Santos et al., 2013), with sandy clay loam texture, whose physical and chemical attributes (Silva, 2009) are described in Table 1.

The crop was established on November 22, 1999, in a $2 \times 1 \mathrm{~m}$ spacing, following east-west orientation. The experiment was carried out in a randomized complete block design in a $2 \times 9 \times 6$ factorial arrangement, with two forms of propagation (seed and cuttings), nine soil sampling spacing distances $(15,30,45,60,75$, and $90 \mathrm{~cm}$ between rows, and 15, 30, and $45 \mathrm{~cm}$ between plants in the rows) - which represented six samples in the career direction, and three between plants -, six soil depths (10-20, 20-30, 30-40, 40-50, and 50$60 \mathrm{~cm}$ ), and six replicates. Each plot consisted of five plants with 12 replicates, until the 2006 harvest, and six replicates until the last harvest (2013). The number of replicates was reduced because some plants were cut off for visual assessment of the root system. In the place of cut plants, cacao plants were grown. In order to avoid interference of cacao plants on the results, only $50 \%$ of the plants that remained in the undisturbed areas were evaluated.

Conventional fertilizers were used from 2002 to 2006, when they were changed to organic fertilizers. After 2006, chemical fertilizers were applied only when soil analyses indicated possible nutrient deficiency. Crop management included irrigation.

Seed- and cutting-propagated plants were harvested 13 times during the growing seasons from 2001 (17-month-old plants) to 2013 (161-month-old plants). Total yield was estimated $\left(\mathrm{kg} \mathrm{ha}^{-1}\right)$ according to individual yields. Harvested coffee at $5.33 \mathrm{~L}$ was considered to provide $1 \mathrm{~kg}$ of processed coffee, according to observations in the field.

Net $\mathrm{CO}_{2}$ assimilation rate (A), stomatal conductance to water vapor $\left(\mathrm{g}_{\mathrm{s}}\right)$, internal $\mathrm{CO}_{2}$ concentration $(\mathrm{Ci})$, and transpiration rates (E) were measured in two leaves, on 12 plants per treatment, using a portable Irga open system Ciras 2, (PP Systems, England). Measurements were taken between 8:00 and 10:00 h. During this interval, plants were subjected to field variations, ranging approximately between: 1,200 and $1,400 \mu \mathrm{mol} \mathrm{m} \mathrm{m}^{-2} \mathrm{~s}^{-1}$ irradiance; 65 and $70 \%$ relative humidity; and 22 and $24^{\circ} \mathrm{C}$; with $380 \mu \mathrm{L} \mathrm{L}^{-1}$ air $\mathrm{CO}_{2}$ concentration. In general, maximum ranges occur by mid-morning (Silva et al., 2004). Determinations were performed in recently matured leaves, from the upper parts of plants.

Chlorophyll (Chl) fluorescence and gas exchange were evaluated on the same leaves, at the same times, using a Ciras 2, PP Systems. The photochemical quenching (qP) (Kooten \& Snell, 1990) and the photosystem II (PSII) energy conversion efficiency 
(Fv'/Fm') (Krüpa et al., 1993) were obtained under steady-state photosynthetic conditions (irradiance of $650 \mu \mathrm{mol} \mathrm{m} \mathrm{m}^{-2} \mathrm{~s}^{-1}$ and saturating flashes of 6,000 $\mu \mathrm{mol} \mathrm{m} \mathrm{m}^{-2} \mathrm{~s}^{-1}$.

In order to evaluate the root system, soil cores were taken from 12 experimental units, 146 months after planting, as follows: six plots with plants derived from seed, and six from cuttings (six replicates). The large number of treatments $(2 \times 9 \times 6)$ and replicates (six plots per treatment) were able to provide a broad knowledge of the root system distribution of 'Conilon' coffee, and made it possible to build maps based on reliable results. Sampled monoliths had $27 \mathrm{~cm}^{3}$ volume $(3 \times 3 \times 3 \mathrm{~cm})$. Samples were stored in plastic bags and refrigerated at approximately $-10^{\circ} \mathrm{C}$ until analysis. The monoliths were washed to separate roots from the soil with running water and 30-mesh sieve. Roots retained in the sieve were transferred to another sieve (60 mesh) and were washed in water again.

Table 1. Soil chemical and textural properties, at six depths, after 146 months of 'Conilon' crop establishment.

\begin{tabular}{|c|c|c|c|c|c|c|}
\hline \multirow[t]{2}{*}{ Variable } & \multicolumn{6}{|c|}{ Soil depth $(\mathrm{cm})$} \\
\hline & $0-10$ & $10-20$ & $20-30$ & $30-40$ & $40-50$ & $50-60$ \\
\hline$\overline{\mathrm{pH}}$ & 5.7 & 5.4 & 5.4 & 5.4 & 5.2 & 5.1 \\
\hline $\mathrm{P}\left(\mathrm{mg} \mathrm{dm} \mathrm{m}^{-3}\right)$ & 28 & 5 & 3 & 2 & 1 & 1 \\
\hline $\mathrm{K}\left(\mathrm{mg} \mathrm{dm}^{-3}\right)$ & 101 & 60 & 43 & 34 & 28 & 24 \\
\hline $\mathrm{S}\left(\mathrm{mg} \mathrm{dm} \mathrm{m}^{-3}\right)$ & 7 & 6 & 7 & 13 & 22 & 26 \\
\hline $\mathrm{Ca}\left(\mathrm{cmol}_{\mathrm{c}} \mathrm{dm}^{-3}\right)$ & 2.0 & 1.4 & 1.2 & 1.0 & 0.9 & 0.7 \\
\hline $\operatorname{Mg}\left(\mathrm{cmol}_{\mathrm{c}} \mathrm{dm}^{-3}\right)$ & 0.5 & 0.3 & 0.2 & 0.2 & 0.2 & 0.1 \\
\hline $\mathrm{Al}\left(\mathrm{cmol}_{\mathrm{c}} \mathrm{dm}^{-3}\right)$ & 0.0 & 0.3 & 0.3 & 0.3 & 0.4 & 0.4 \\
\hline $\mathrm{H}+\mathrm{Al}\left(\mathrm{cmol}_{\mathrm{c}} \mathrm{dm}^{-3}\right)$ & 2.6 & 2.1 & 2.0 & 2.0 & 1.8 & 2.1 \\
\hline $\mathrm{Na}\left(\mathrm{mg} \mathrm{dm}^{-3}\right)$ & 49 & 34 & 27 & 26 & 25 & 22 \\
\hline $\mathrm{SB}\left(\mathrm{cmol}_{\mathrm{c}} \mathrm{dm}^{-3}\right)$ & 2.8 & 1.9 & 1.5 & 1.3 & 1.2 & 0.9 \\
\hline $\mathrm{E}\left(\mathrm{cmol}_{\mathrm{c}} \mathrm{dm}^{-3}\right)$ & 5.4 & 4.0 & 3.5 & 3.3 & 3.0 & 3.0 \\
\hline $\operatorname{CEC}\left(\mathrm{cmol}_{\mathrm{c}} \mathrm{dm}^{-3}\right)$ & 2.8 & 2.2 & 1.8 & 1.6 & 1.6 & 1.3 \\
\hline $\mathrm{OM}\left(\mathrm{dag} \mathrm{kg}^{-1}\right)$ & 1.9 & 1.1 & 0.9 & 0.8 & 0.7 & 0.5 \\
\hline $\mathrm{m}(\%)$ & 0 & 14 & 17 & 19 & 25 & 32 \\
\hline V $(\%)$ & 51.5 & 46.9 & 43.0 & 39.2 & 39.4 & 29.1 \\
\hline $\mathrm{Fe}\left(\mathrm{mg} \mathrm{dm}^{-3}\right)$ & 74 & 108 & 125 & 121 & 125 & 110 \\
\hline $\mathrm{Cu}\left(\mathrm{mg} \mathrm{dm}^{-3}\right)$ & 0.5 & 0.3 & 0.3 & 0.2 & 0.2 & 0.2 \\
\hline $\mathrm{Zn}\left(\mathrm{mg} \mathrm{dm}^{-3}\right)$ & 6.7 & 2.4 & 0.6 & 0.2 & 0.2 & 0.2 \\
\hline $\operatorname{Mn}\left(\mathrm{mg} \mathrm{dm}^{-3}\right)$ & 42 & 35 & 33 & 20 & 9 & 7 \\
\hline$\underline{B}\left(\mathrm{mg} \mathrm{dm}^{-3}\right)$ & 0.82 & 0.77 & 0.47 & 0.30 & 0.27 & 0.23 \\
\hline Total sand $\left(\mathrm{g} \mathrm{kg}^{-1}\right)$ & 610 & 586 & 582 & 520 & 524 & 500 \\
\hline Silt $\left(\mathrm{g} \mathrm{kg}^{-1}\right)$ & 150 & 154 & 138 & 160 & 156 & 140 \\
\hline Clay $\left(\mathrm{g} \mathrm{kg}^{-1}\right)$ & 240 & 260 & 280 & 320 & 320 & 360 \\
\hline Soil density $\left(\mathrm{g} \mathrm{cm}^{-3}\right)$ & 1.06 & 1.25 & 1.51 & 1.51 & 1.65 & 1.65 \\
\hline
\end{tabular}

$\mathrm{SB}$, sum of bases; E, cation exchange capacity at $\mathrm{pH}$ 7.0; CEC, effective cation exchange capacity; OM, organic matter; $\mathrm{m}$, aluminium saturation index; $\mathrm{V}$, base saturation index.
The washed roots were photographed with a digital camera and, subsequently, they were analyzed using the Safira software, which is an analysis system for fibres and roots (Embrapa Instrumentação Agropecuária, São Carlos, SP, Brazil) (Jorge \& Rodrigues, 2008), in order to quantify length, volume, surface area, and diameter of roots. Fine root content per volume $\left(\mathrm{cm}^{3}\right)$ of soil was estimated with roots with less than $1 \mathrm{~mm}$ diameter.

Nonnormally distributed data associated with root diameter, surface area, length, and volume were transformed $[y=\log (x+1)]$ prior to the analysis of variance and comparison of means; notwithstanding, the original data were shown.

Statistical analysis was performed using Assistat 7.6 (Silva, 2012). Data were subjected to the analysis of variance, following a Box-Cox transformation. Means were compared by Tukey's test, at 5\% probability.

Isoline diagrams were drawn using the GS+ version 7 software (Gamma Design Software, Plainwell, Michigan, USA), in order to illustrate the spatial distribution of the root system in the soil profile, in two dimensions.

\section{Results and Discussion}

The yield of cutting-propagated plants was significantly higher in the $1^{\text {st }}, 2^{\text {nd }}, 4^{\text {th }}, 8^{\text {th }}, 10^{\text {th }}$ and $13^{\text {th }}$ harvests (Table 2), whereas seed-propagated plants did not show significantly higher yields in none of the studied years. The highest yield difference between the two groups of plants was found after the first two harvests. The overall production along the experimental period was $43,788 \mathrm{~kg} \mathrm{ha}^{-1}$ for cutting- propagated plants, and 35,644 $\mathrm{kg} \mathrm{ha}^{-1}$ for seed-propagated ones. Additionally, the average annual yields for the 13-year period were respectively 3,368 and $2,742 \mathrm{~kg} \mathrm{ha}^{-1}$. Therefore, cutting-propagated plants had a significantly higher yield during the trial, showing a clear advantage over the seed-propagated ones.

Plants derived from cuttings had earlier production capability, which might be caused by the greater physiological maturity of these individuals. In that respect, these plants were able to develop a higher number of productive (plagiotropic) branches sooner than seed-derived ones. This might be related to the fact that 'Conilon' clones are produced from cuttings of physiologically differentiated tissue (Bragança et al., 2001). In contrast, seed-derived plants are able 
to develop plagiotropic (i.e., productive) branches only by the ninth or tenth leaf axil. This difference delays fruiting stage and the full production potential of plants, which was clearly observed in the first four years of this experiment. These findings agree with Carvalho et al. (2011), who observed that $C$. arabica 'Catuaí' plants had a better initial development when derived from vegetative propagation (somatic embryogenesis). However, the higher yields observed for plants derived from cuttings may also have been caused by the better genetic material used for the propagation of these plants.

Net photosynthetic $\mathrm{CO}_{2}$ assimilation, stomatal conductance to watervapor, internal $\mathrm{CO}_{2}$ concentrations, and instantaneous water-use efficiency did no differ between propagation methods (Table 3). Moreover, the energy harvesting efficiency and photochemical quenching were also statistically similar.

Regarding the root system, the average diameter of lateral roots was significantly higher in plants derived from seed (Table 4 and Figure 1), mostly due to data variation in depth, since no differences were observed in the horizontal position (distance from the coffee tree trunk). Seed-grown plants had a significantly greater diameter in the 50-60 cm layer, which was similar to that reported for C. arabica plants (Rena \& Guimarães, 2000).

When comparing root concentrations according to the horizontal distance from the trees, the first centimetres of the top-soil layer had greater values of root length and volume between rows than the ones observed within rows (Figure 2). The area between plants in the rows did not receive topdressing fertilization. Therefore, this result most likely occurred because of the higher fertility in the space between rows (Sousa et al., 2002).

Root surface area, length, and volume did not differ between the propagation methods in none of the evaluated distances or depths (Table 5 and Figure 2). Therefore, under the particular conditions of this study, the root system of 'Conilon' coffee was not affected by the propagation method. This finding contrasts with the results reported for C. arabica, in which total root length and dry weight of cutting-propagated plants were greater than those of seed-propagated ones (Jesus et al., 2006).

No interaction was observed between the evaluated distances and depths, for data related to root surface area, length, and volume. Roots had a higher concentration in the top soil layer $(0-10 \mathrm{~cm})$, which decreased with depth (Table 6). Roots had lower concentrations in the layers below $40 \mathrm{~cm}$, showing a parallel with nutrient concentrations ( $\mathrm{P}, \mathrm{K}$, and $\mathrm{Ca}$ ) (Table 1). The spatial distribution of roots in the soil profile confirmed these trends (Figures 2). Mota et al. (2006) reported the highest concentration of coffee roots up to $0.20 \mathrm{~m}$ depth, and Rodrigues et al. (2001) observed lower root concentrations at deeper soil layers. This behavior of

Table 2. Yield of Coffea canephora 'Conilon' propagated by seed or cuttings, from 2001 (17 months) to 2013 (161 months) ${ }^{(1)}$.

\begin{tabular}{lccccccccccccc}
\hline Propagation & 2001 & 2002 & 2003 & 2004 & 2005 & 2006 & 2007 & 2008 & 2009 & 2010 & 2011 & 2012 & 2013 \\
\hline Cutting & $421 \mathrm{a}$ & $5,795 \mathrm{a}$ & $1,629 \mathrm{a}$ & $3,135 \mathrm{a}$ & $1,562 \mathrm{a}$ & $4,325 \mathrm{a}$ & $2,330 \mathrm{a}$ & $4,349 \mathrm{a}$ & $2,861 \mathrm{a}$ & $4,410 \mathrm{a}$ & $3,812 \mathrm{a}$ & $4,051 \mathrm{a}$ & $5,107 \mathrm{a}$ \\
Seed & $73 \mathrm{~b}$ & $3,220 \mathrm{~b}$ & $1,269 \mathrm{a}$ & $2,355 \mathrm{~b}$ & $1,549 \mathrm{a}$ & $3,745 \mathrm{a}$ & $2,513 \mathrm{a}$ & $3,446 \mathrm{~b}$ & $2,977 \mathrm{a}$ & $3,099 \mathrm{~b}$ & $4,051 \mathrm{a}$ & $4,170 \mathrm{a}$ & $3,178 \mathrm{~b}$ \\
\hline CV $(\%)$ & 50.2 & 16.9 & 35.3 & 26.2 & 34.9 & 27.4 & 22.2 & 26.1 & 45.6 & 17.66 & 33.23 & 26.26 & 30.04 \\
\hline
\end{tabular}

${ }^{(1)}$ Means followed by equal letters, in the columns, do not differ, by Tukey’s test, at $5 \%$ probability.

Table 3. Net photosynthesis (A), stomatal conductance to water vapor (gs), internal $\mathrm{CO}_{2}$ concentration (Ci), transpiration (E), and two parameters for chlorophyll fluorescence (Fv'/Fm', qP) of Coffea canephora 'Conilon' plants propagated by seed or cuttings.

\begin{tabular}{|c|c|c|c|c|c|c|}
\hline Propagation & $\begin{array}{c}\mathrm{A} \\
\left(\mu \mathrm{mol} \mathrm{m} \mathrm{m}^{-2} \mathrm{~s}^{-1} \mathrm{CO}_{2}\right) \\
\end{array}$ & $\begin{array}{c}\text { Gs } \\
\left(\mathrm{mmol} \mathrm{m} \mathrm{m}^{-2} \mathrm{~s}^{-1} \mathrm{H}_{2} \mathrm{O}\right) \\
\end{array}$ & 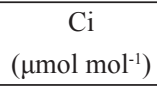 & $\begin{array}{c}\mathrm{E} \\
\left(\mathrm{mmol} \mathrm{m} \mathrm{m}^{-2} \mathrm{~s}^{-1} \mathrm{H}_{2} \mathrm{O}\right) \\
\end{array}$ & Fv'/Fm' & $\mathrm{qP}^{\prime}$ \\
\hline Cutting & $13.88 \mathrm{a}$ & $85.12 \mathrm{a}$ & $230.58 \mathrm{a}$ & $1.76 \mathrm{a}$ & $0.60 \mathrm{a}$ & $0.49 \mathrm{a}$ \\
\hline$\underline{\text { Seed }}$ & $13.01 \mathrm{a}$ & $98.02 \mathrm{a}$ & $227.17 \mathrm{a}$ & $1.59 \mathrm{a}$ & $0.62 \mathrm{a}$ & $0.49 \mathrm{a}$ \\
\hline CV (\%) & 13.88 & 39.04 & 27.51 & 15.02 & 6.45 & 28.99 \\
\hline
\end{tabular}

${ }^{(1)}$ Means followed by equal letters, in the columns, do not differ, by Tukey's test, at 5\% probability. Fv'/Fm', photochemical efficiency of PS II under photosynthetic steady-state conditions; $\mathrm{qP}$, photochemical quenching. 
root systems can also be observed for other species, such as passion fruit (Sousa et al., 2002; Lucas et al., 2012) and orange rootstocks (Zaccheo et al., 2012).

Although root development in coffee is mainly related to the genetic characteristics of the plant (Martins et al., 2013), other factors may also interfere in the spatial distribution, such as the propagation form, seedling stage, and amount of water in the soil (Franco \& Inforzato, 1946). The availability of soil nutrients

Table 4. Root diameter (mm) of Coffea canephora 'Conilon' propagated by seed or cuttings at different soil depths ${ }^{(1)}$.

\begin{tabular}{lcc}
\hline Soil depth $(\mathrm{m})$ & Cuttings & Seed \\
\hline $0-10$ & $0.659 \mathrm{Aa}$ & $0.687 \mathrm{Aa}$ \\
$10-20$ & $0.704 \mathrm{Aa}$ & $0.700 \mathrm{Aa}$ \\
$20-30$ & $0.770 \mathrm{Aa}$ & $0.741 \mathrm{Aa}$ \\
$30-40$ & $0.679 \mathrm{Aa}$ & $0.703 \mathrm{Aa}$ \\
$40-50$ & $0.636 \mathrm{Aa}$ & $0.673 \mathrm{Aa}$ \\
$50-60$ & $0.415 \mathrm{Bb}$ & $0.592 \mathrm{Ba}$ \\
\hline CV $(\%)$ & 37.89 & 32.45 \\
\hline
\end{tabular}

(1)Means followed by equal letters, lowercase in the rows and uppercase in the columns, do not differ by Tukey's test, at $5 \%$ probability.

A
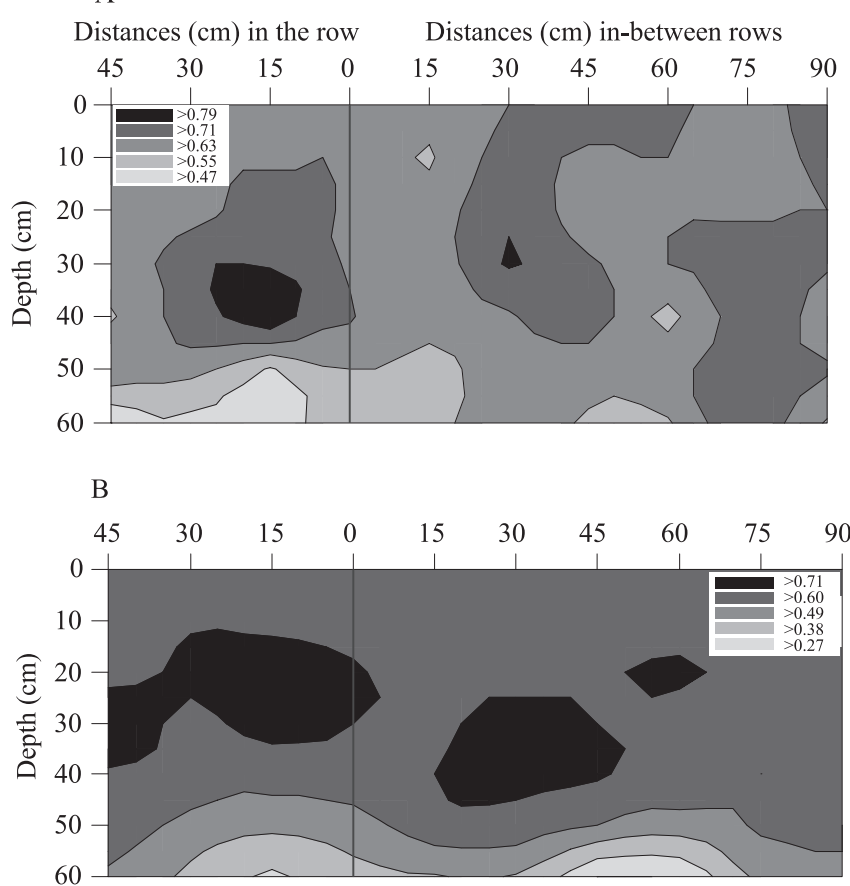

Figure 1. Spatial distribution of the root diameters $(\mathrm{mm})$ of Coffea canephora 'Conilon', propagated by seed (A) or cuttings (B), at different horizontal distances and depths. The zero point refers to the plant location. to plants can also influence the deep root density and distribution (Bakker et al., 2006). According to Witschoreck et al. (2003), the concentration of fine roots in the soil surface layer is related to the higher concentrations of organic matter and nutrients, and to favorable physical conditions. Nutrient availability can be a limiting factor for coffee root development, particularly for Brazilian soils (Rena \& Guimarães, 2000).
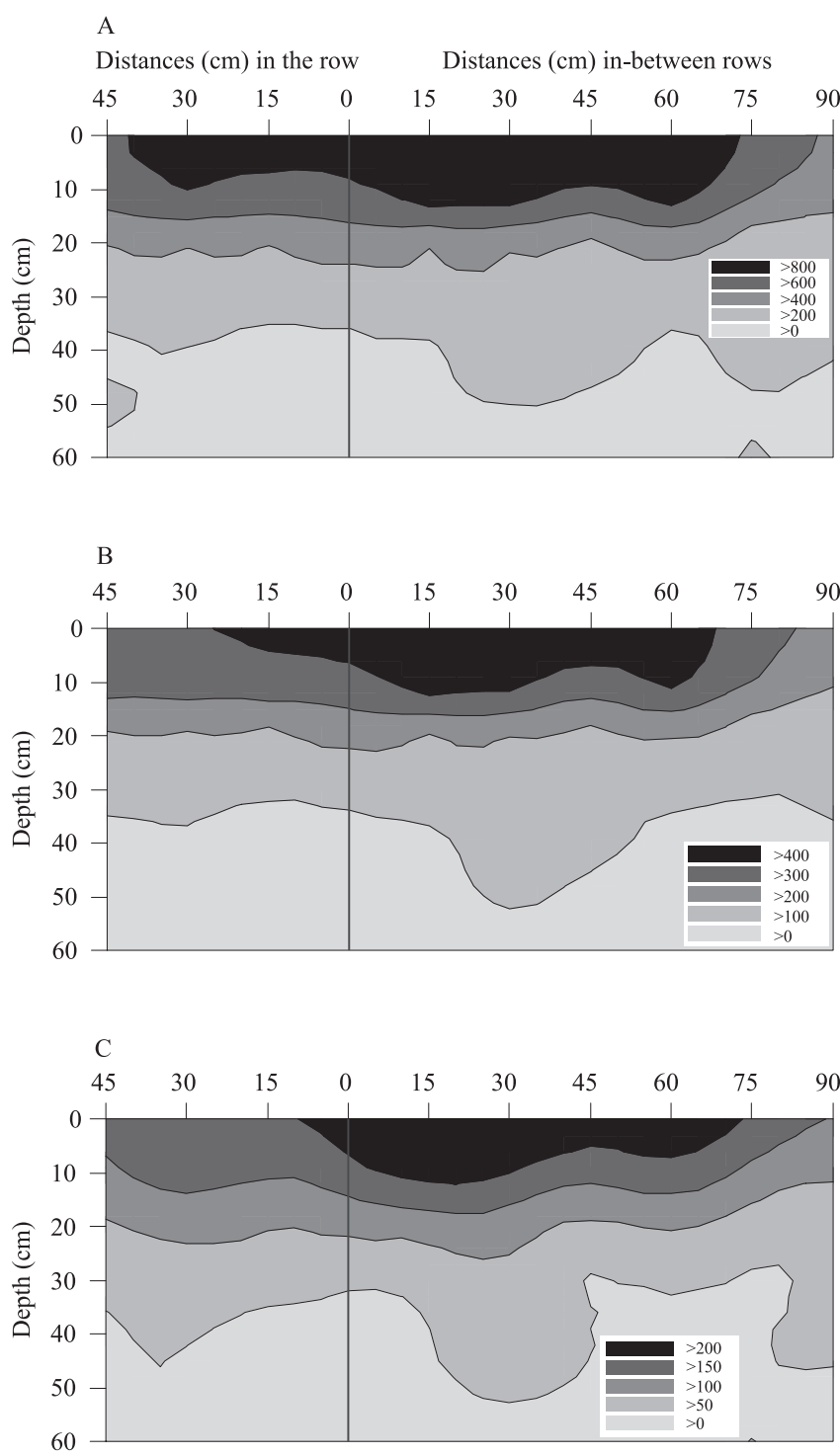

Figure 2. Spatial distribution of: $\mathrm{A}$, root surface area $\left(\mathrm{cm}^{2} \mathrm{dm}^{-3}\right)$; $\mathrm{B}$, root length $\left(\mathrm{m} \mathrm{dm}^{-3}\right)$; and $\mathrm{C}$, root volume $\left(\mathrm{mm}^{3}\right)$ for Coffea canephora 'Conilon' propagated by seed or cuttings, at different horizontal distances and depths. The zero point refers to the plant location. 
Table 5. Surface area, length, and volume of Coffea canephora 'Conilon' roots propagated by seed or cuttings, at different spacing distances and depths.

\begin{tabular}{|c|c|c|c|c|c|c|c|c|c|}
\hline \multirow{2}{*}{$\begin{array}{l}\text { Soil depth } \\
(\mathrm{cm})\end{array}$} & \multicolumn{6}{|c|}{ Distances between rows $(\mathrm{cm})$} & \multicolumn{3}{|c|}{ Distances within rows $(\mathrm{cm})$} \\
\hline & 15 & 30 & 45 & 60 & 75 & 90 & 15 & 30 & 45 \\
\hline & \multicolumn{9}{|c|}{ Surface area $\left(\mathrm{cm}^{2} \mathrm{dm}^{-3}\right)$} \\
\hline $0-10$ & 977.2 & 974.4 & 773.1 & 952.1 & 651.6 & 509.9 & 757.1 & 828.4 & 724.9 \\
\hline $10-20$ & 404.7 & 414.2 & 343.1 & 472.4 & 271.6 & 247.7 & 394.0 & 409.6 & 393.0 \\
\hline $20-30$ & 377.5 & 384.8 & 187.6 & 284.2 & 226.3 & 291.4 & 297.9 & 323.8 & 303.2 \\
\hline $30-40$ & 156.2 & 402.0 & 307.7 & 148.6 & 265.5 & 206.1 & 113.4 & 193.0 & 149.5 \\
\hline $40-50$ & 167.9 & 194.2 & 151.4 & 143.7 & 184.9 & 172.4 & 95.1 & 182.2 & 251.3 \\
\hline \multirow[t]{2}{*}{$\underline{50-60}$} & 104.7 & 112.7 & 97.1 & 111.3 & 219.4 & 133.8 & 88.9 & 146.3 & 139.6 \\
\hline & \multicolumn{9}{|c|}{ Length $\left(\mathrm{m} \mathrm{dm}^{-3}\right)$} \\
\hline $0-10$ & 471.5 & 445.7 & 357.4 & 435.7 & 303.1 & 210.8 & 368.5 & 356.8 & 346.2 \\
\hline $10-20$ & 177.1 & 191.7 & 156.9 & 199.4 & 125.2 & 114.4 & 165.5 & 179.7 & 180.6 \\
\hline $20-30$ & 171.8 & 152.8 & 79.5 & 129.0 & 106.7 & 122.8 & 116.4 & 139.5 & 127.0 \\
\hline $30-40$ & 68.2 & 174.9 & 134.0 & 66.1 & 112.8 & 85.7 & 44.7 & 85.3 & 73.7 \\
\hline $40-50$ & 66.6 & 115.7 & 67.0 & 57.2 & 82.8 & 88.2 & 37.6 & 57.1 & 103.9 \\
\hline \multirow[t]{2}{*}{$\underline{50-60}$} & 31.2 & 61.3 & 49.7 & 46.9 & 91.9 & 61.5 & 32.6 & 59.3 & 63.8 \\
\hline & \multicolumn{9}{|c|}{ Volume $\left(\mathrm{mm}^{3}\right)$} \\
\hline $0-10$ & 244.6 & 207.1 & 160.7 & 197.1 & 137.9 & 119.3 & 148.6 & 187.1 & 141.2 \\
\hline $10-20$ & 87.6 & 113.7 & 74.0 & 110.2 & 57.9 & 52.3 & 97.2 & 100.8 & 84.4 \\
\hline $20-30$ & 86.6 & 98.6 & 42.5 & 59.2 & 45.0 & 74.5 & 76.7 & 77.0 & 74.0 \\
\hline $30-40$ & 35.3 & 100.2 & 68.5 & 30.7 & 61.6 & 51.1 & 28.9 & 45.3 & 27.4 \\
\hline $40-50$ & 42.3 & 58.7 & 33.9 & 42.0 & 40.2 & 43.6 & 24.7 & 60.6 & 60.2 \\
\hline $50-60$ & 30.1 & 25.7 & 18.1 & 28.5 & 51.3 & 26.7 & 25.6 & 34.2 & 28.5 \\
\hline
\end{tabular}

Table 6. Surface area, length, and volume of roots of Coffea canephora 'Conilon' propagated by seed or cuttings at different soil depths.

\begin{tabular}{lccc}
\hline Depth $(\mathrm{cm})$ & Surface area $\left(\mathrm{cm}^{2} \mathrm{dm}^{-3}\right)$ & Length $\left(\mathrm{m} \mathrm{dm}^{-3}\right)$ & Volume $\left(\mathrm{mm}^{3}\right)$ \\
\hline & \multicolumn{3}{c}{ Absolute values } \\
$0-10$ & $794.3 \mathrm{a}$ & $366.2 \mathrm{a}$ & $171.5 \mathrm{a}$ \\
$10-20$ & $372.3 \mathrm{~b}$ & $165.6 \mathrm{~b}$ & $86.4 \mathrm{~b}$ \\
$20-30$ & $297.4 \mathrm{bc}$ & $127.3 \mathrm{bc}$ & $70.5 \mathrm{bc}$ \\
$30-40$ & $215.8 \mathrm{~cd}$ & $93.9 \mathrm{~cd}$ & $49.9 \mathrm{~cd}$ \\
$40-50$ & $174.4 \mathrm{~cd}$ & $75.1 \mathrm{~cd}$ & $45.1 \mathrm{~cd}$ \\
$50-60$ & $128.2 \mathrm{~d}$ & $55.4 \mathrm{~d}$ & $29.9 \mathrm{~d}$ \\
\hline CV $(\%)$ & 37.71 & 37.89 \\
\hline & \multicolumn{3}{c}{ Percentual values } \\
$0-10$ & 40.13 & 41.45 & 37.28 \\
$10-20$ & 18.81 & 18.75 & 19.06 \\
$20-30$ & 15.03 & 14.41 & 15.55 \\
$30-40$ & 10.90 & 10.63 & 11.00 \\
$40-50$ & 8.66 & 8.50 & 9.94 \\
$50-60$ & 6.84 & 6.27 & 6.59 \\
\hline
\end{tabular}

(1)Means followed by equal letters, in the columns, do not differ, by Tukey's test, at $5 \%$ probability.

\section{Conclusions}

1. Cutting-propagated plants of Coffea canephora 'Conilon' are more productive than seed-propagated ones.
2. Surface area, length, and volume of 'Conilon' roots are not affected by the propagation method, and show higher values in the soil surface, in-between the rows.

\section{Acknowledgements}

To Coordenação de Aperfeiçoamento de Pessoal de Nível Superior (Capes) and to the Universidade Federal do Espírito Santo (Ufes), for partial support of this work; and to Mr. Valnei Marcos Partelli, for permitting the use of the experimental area.

\section{References}

ANDRADE JÚNIOR, S. de; ALEXANDRE, R.S.; SCHMILDT, E.R.; PARTELLI, F.L.; FERRÃO, M.A.G.; MAURI, A.L. Comparison between grafting and cutting as vegetative propagation methods for 'Conilon' coffee plants. Acta Scientiarum. Agronomy, v.35, p.461-469, 2013. DOI: 10.4025/actasciagron.v35i4.16917.

BAKKER, M.R.; AUGUSTO, L.; ACHAT, D.L. Fine root distribution of trees and understory in mature stands of maritime pine (Pinus pinaster) on dry and humid sites. Plant Soil, v.286, p.37-51, 2006. DOI: 10.1007/s11104-006-9024-4.

BRAGANÇA, S.M.; CARVALHO, C.H.S. de; FONSECA, A.F.A. da; FERRÃO, R.G. Variedades clonais de café Conilon lançadas para 
o Estado do Espírito Santo. Pesquisa Agropecuária Brasileira, v.36, p.765-770, 2001. DOI: 10.1590/S0100-204X2001000500006.

CARVALHO, C.H.S. de; REZENDE, J.C. de; ALMEIDA, G.R.R.; TEIXEIRA, J.B.; PADILHA, L. Características agronômicas e morfológicas de cafeeiro 'Catuaí Vermelho' propagado por embriogênese somática. Pesquisa Agropecuária Brasileira, v.46, p.378-383, 2011. DOI: 10.1590/S0100-204X2011000400006.

CARVALHO, M.; JESUS, A.M.S.; CARVALHO, S.P.; GOMES, C.N.; SOARES, A.M. Comportamento em condições de campo de cafeeiros (Coffea arabica L.) propagados vegetativamente e por semeadura. Coffee Science, v.3, p.108-114, 2008.

COMITÊ DE BACIA HIDROGRÁFICA DO RIO DOCE. A bacia do Rio Doce: característica da bacia. Disponível em: $<$ http://www.riodoce. cbh.gov.br/bacia_caracterizacao.asp > . Acesso em: 2 mar. 2013.

CONAGIN, C.H.T.M.; MENDES, A.J.T. Pesquisas citológicas e genéticas em três espécies de Coffea. Auto-incompatibilidade em Coffea canéfora pierre ex froehner. Bragantia, v.20, p.787-804, 1961. DOI: 10.1590/S0006-87051961000100034.

FRANCO, C.M.; INFORZATO, R. O sistema radicular do cafeeiro nos principais tipos de solo do Estado de São Paulo. Bragantia, v.6, p.443-458, 1946. DOI: 10.1590/S0006-87051946000900001.

JESUS, A.M.S.; CARVALHO, S.P.; SOARES, A.M. Comparação entre sistemas radiculares de mudas de Coffea arabica L. obtida por estaquia e por sementes. Coffea Science, v.1, p.14-20, 2006.

JORGE, L.A. de C.; RODRIGUES, A.F. de O. Safira: sistema de análise de fibras e raízes. São Carlos: Embrapa Instrumentação Agropecuária, 2008. 21p. (Embrapa Instrumentação Agropecuária. Boletim de pesquisa e desenvolvimento, 24).

KOOTEN, O. van; SNELL, J.F.H. The use of chlorophyll fluorescence nomenclature in plant stress physiology. Photosynthesis Research, v.25, p.147-150, 1990. DOI: 10.1007/BF00033156.

KRÜPA, Z.; ÖQUIST, G.; HUNER, N.P. The effects of cadmium on photosynthesis of Phaseolus vulgaris: a fluorescence analysis. Physiologia Plantarum, v.88, p.626-630, 1993. DOI: 10.1111/ j.1399-3054.1993.tb01381.x.

LUCAS, A.A.T.; FRIZZONE, J.A.; COELHO FILHO, M.A. Características da distribuição radicular de maracujazeiro sob fertirrigação. Irriga, v.17, p.245-250, 2012.

LYNCH, L. Root architecture and plant productivity. Plant Physiology, v.109, p.7-13, 1995.

MARTINS, L.D.; TOMAZ, M.A.; AMARAL, J.F.T. do; BRAGANÇA, S.M.; RODRIGUES, W.N.; REIS, E.F. dos. Nutritional efficiency in clones of Conilon coffee for phosphorus. Journal of Agricultural Science, v.5, p.130-140, 2013.

MIRANDA, W.L.; GUIMARÃES, R.J.; MAGALHÃES, P.B.; COLOMBO, A.; OLIVEIRA, P.M. de O. Desenvolvimento vegetativo de plantas de café arábica enxertadas sobre café robusta e submetidas à reposição hídrica. Pesquisa Agropecuária Brasileira, v.46, p.1618-1624, 2011. DOI: 10.1590/ S0100-204X2011001200006.
MOTA, A.C.V.; NICK, J.A.; YORINORI, G.T.; SERRAT, B.M. Distribuição horizontal e vertical da fertilidade do solo e das raízes de cafeeiro (Coffea arabica L.) cultivar Catuaí. Acta Scientiarum. Agronomy, v.28, p.455-463, 2006. DOI: 10.4025/actasciagron. v28i4.758.

PAIVA, R.F. de; MENDES, A.N.G.; CARVALHO, G.R.; REZENDE, J.C. de; FERREIRA, A.D.; CARVALHO, A.M. de. Comportamento de cultivares de cafeeiros C. arabica L. enxertados sobre cultivar 'Apoatã IAC 2258' (Coffea canephora). Ciência Rural, v.42, p.1155-1160, 2012. DOI: 10.1590/ S0103-84782012000700003.

RENA,A.B.; GUIMARÃES, P.T.G. Sistema radicular do cafeeiro: estrutura, distribuição, atividade e fatores que o influenciam. Belo Horizonte: Epamig, 2000. 80p. (EPAMIG. Documentos, 37).

RODRIGUES, L.A.; MARTINEZ, H.E.P.; NEVES, J.C.L.; NOVAIS, R.F.; MENDONÇA, S.M. Growth response of coffee tree shoots and roots to subsurface liming. Plant and Soil, v.234, p.207-214, 2001. DOI: 10.1023/A:1017999318532.

SANTOS, H.G. dos; JACOMINE, P.K.T.; ANJOS, L.H.C. dos; OLIVEIRA, V.A. de; LUMBRERAS, J.F.; COELHO, M.R.; ALMEIDA, J.A. de; CUNHA, T.J.F.; OLIVEIRA, J.B. de. Sistema brasileiro de classificação de solos. 3.ed. rev. e ampl. Brasília: Embrapa, 2013. 353p.

SILVA, E.A.; DAMATTA, F.M.; DUCATTI, C.; REGAZZI, A.J.; BARROS, R.S. Seasonal changes in vegetative growth and photosynthesis of Arabica coffee trees. Field Crops Research, v.89, p.349-357, 2004. DOI: 10.1016/j.fcr.2004.02.010.

SILVA, F.A.S. Assistat - statistical assistance. Versão 7.6 beta. 2012. Disponível em: <http://www.assistat.com/indexi.html >. Acesso em: 15 mar. 2012.

SILVA, F.C. da. Manual de análises químicas de solos, plantas e fertilizantes. 2.ed. rev. ampl. Brasília: Embrapa Informação Tecnológica; Rio de Janeiro: Embrapa Solos, 2009. 627p.

SOUSA, V.F.; FOLEGATTI, M.V.; COELHO FILHO, M.A.; FRIZZONE, J.A. Distribuição radicular do maracujazeiro sob diferentes doses de potássio aplicadas por fertirrigação. Revista Brasileira de Engenharia Agrícola e Ambiental, v.6, p.51-56, 2002. DOI: $10.1590 / \mathrm{S} 1415-43662002000100010$.

WEIGEL, D.; JURGENS, G. Stem cells that make stems. Nature, v.415, p.751-754, 2002. DOI: 10.1038/415751a.

WITSCHORECK, R.; SCHUMACHER, M.V.; CALDEIRA, M.V.W. Estimativa da biomassa e do comprimento de raízes finas em Eucalyptus urophylla S.T. Blake no Município de Santa Maria-RS. Revista Árvore, v.27, p.177-183, 2003. DOI: 10.1590/ S0100-67622003000200008.

ZACCHEO, P.V.C.; NEVES, C.S.V.J.; STENZEL, N.M.C.; OKUMURA, R.S. Distribuição do sistema radicular de porta-enxertos sob laranjeira 'Folha Murcha' em clima subtropical. Semina: Ciências Agrárias, v.33, p.921-930, 2012. DOI: 10.5433/1679-0359.2012v33n3p921. 